\title{
I2. COMMISSION DE LA RADIATION SOLAIRE ET DE LA SPECTROSCOPIE SOLAIRE
}

\author{
Président: M. G. Abetti, Direttore dell' Osservatorio Astrofisico, Arcetri-Firenze (3R), \\ Italia.
}

Membres: MM. Abbot, H. D. Babcock, Mme Nováková Bednaróva, MM. Brück, P. Carrasco, Carroll, Chalonge, Chandrasekhar, S. Chapman, Cowling, d'Azambuja, Dingle, Evershed, A. S. King, Lyot, McCrea, Menzel, Migeotte, Milne, Minnaert, Münch-Paniagua, Pannekoek, Pettit, Plaskett, Randers, Righini, Russell, Rutllant, Shane, Mme Moore Sitterly, MM. B. Strömgren, Waldmeier, Wildt, Woolley.

The report is compiled from information supplied by several members, in response to a request for information. Several members replied that they are not now actively concerned with the subjects with which this Commission is dealing. No attempt has been made to review the work done in these subjects in the years since the last General Assembly of 1938 .

Daily determinations of the solar constant have been continued by the staff of the Astrophysical Observatory of the Smithsonian Institution at Montezuma (Chile) and at Table Mountain (U.S.). Apparatus and methods are being developed by Abbot and his co-operators for the daily measurement of atmospheric ozone and of its band of absorption, 9-Io $\mu$. Intensity of solar radiation at ground-level has also been measured for some years in several wave-length regions in the ultra-violet, as well as in the visible and near infra-red. Abbot has discussed the variations and their effects on terrestrial temperatures and on precipitation; a revised analysis of solar constant values has also been made by Abbot, who has found a depression of solar constant values associated with terrestrial magnetic storms and other meteorological phenomena.

Measurements of solar radiation with various filters and of sky illumination at various high altitude stations seem desirable, in order to investigate the conditions for suitability for observations of the outer layers of the Sun and particularly of the corona.

Recent contributions to solar spectroscopy have opened new fields of research as well as improving and completing existing data. The principal ones include the explanation of the generation of stellar energy by means of the carbon cycle of nuclear transformations by Bethe; a determination of the amount of hydrogen and of helium in the Sun by Schwarzschild; the extension of the observable solar spectrum to $2200 \mathrm{~A}$. with the aid of rockets by Durand, Oberly and Tousey; discovery and extensive study of radiation emitted by the Sun in the range of frequencies from 60 to $300 \mathrm{Mcyc}$./sec. and also in the microwave region at 24,000 Mcyc./sec.; observations which appear to show the presence of a general magnetic field in the Sun by Thiessen; a study of chemical compounds in the Sun by Babcock; the extension of high resolution in the spectrum to $2 \mu$ with the $\mathrm{PbS}$ photocell by McMath and Mohler; the extension of the photographic solar spectrum to I3,495 A. by Babcock and Moore Sitterly; and a revision of the high dispersion solar spectrum, 2935-3063 A. by Babcock, Moore Sitterly and Coffeen.

Thiessen concluded that the polar intensity of the Sun's field is about 50 gauss and that the polarity is the same as that found by Hale. His null method utilizes visual observations, chiefly on one line in the spectrum. Babcock began work on this subject in I940, which is not yet completed; the photographic method is used for simultaneous observation of numerous lines in the spectrum produced by a Lummer plate crossed by a grating. The analyser transmits polarized light of one sign for certain lines, of opposite sign for others, and unpolarized light for still others. The sensitivity is adequate but the results are not yet decisive. Better conditions for such observations may be expected with the waning of the present sunspot maximum. McCrea thinks that it would be of great value if the whole of the existing data on the Sun's general magnetic field could be reviewed.

Babcock has extended the early work of Russell on compounds in the Sun, and found bands in sunspots arising from vibrational and electronic states of $\mathrm{O}_{2}$ and $\mathrm{CN}$ well above 
the ground-level, as well as numerous extensions to band systems previously known in the Sun. He has listed about roo band heads identified in spots.

McMath and Mohler report excellent results from the use of a $\mathrm{PbS}$ cell in a selfregistering spectrograph. Wave-lengths and intensities are given directly from the record. Several elements have been recognized in the region $\mathrm{I} \cdot 5-2 \cdot 0 \mu$ by comparison of the solar data with predicted positions of their lines. In the region $12,700 \mathrm{~A}$. their records are in excellent agreement with Babcock's photographic data.

The work of Babcock and Moore Sitterly on the solar spectrum from 6600 to $13,495 \mathrm{~A}$. is in the Press. Wave-lengths and intensities are given for over 7400 lines, of which about one half are atmospheric. With the aid of the Utrecht Atlas and Allen's data, intensities of lines in the spectrum of the solar disk are calibrated in terms of equivalent width. In the sunspot spectrum estimated intensities extend to II,404 A. The identifications are based on a critical study of laboratory data and include several hundred predicted lines not yet observed in artificial sources. Excitation potentials are given for all classified lines. The sixty-six elements now recognized in solar spectra are listed.

Babcock, Moore Sitterly and Coffeen give a thorough revision of earlier descriptions of the ultra-violet limit of the solar spectrum, as observed from ground-level. Wavelengths and estimated intensities are listed for 665 solar lines in the region 2935-3063 A. and three-fourths of these are identified. Five hundred additional lines 3063-3I53 A. have been measured as a further check on the Revised Rowland data, but these are not published since it is concluded that the labour of remeasuring the rest of the ultra-violet and the visible regions is not justified.

Special attention is called to the additional revised identifications of solar lines now worked out by Moore Sitterly, in the range 3063-6600 A., but not yet published. These lines have now been studied as completely as those in the infra-red and in the 2935-3063 A. region.

Babcock, Russell and myself propose a resolution, to be sponsored jointly by Commissions I2 and I4, to the effect that the Union should consider giving financial aid to the publication of a revised description of the solar spectrum, such revision to contain wave-lengths on the scale of I928, measured intensities or equivalent widths from Utrecht, and definitive identifications from Moore Sitterly.

Discussion of such a resolution should develop more clearly the best procedure for producing an authoritative statement of existing solar data. The wording above purposely omits the range to be covered. To be justified, such a publication would have to include the visual and most of the high dispersion ultra-violet. Whether a greater range should be included and whether data on sunspot spectra can be sufficiently expressed by statistical relations, now fairly well established, are open questions.

Mrs Moore Sitterly points out that the compilation of atomic energy levels ( $\mathrm{Cir} . \mathrm{Nat}$. Bur. St. 467, Vol. I, ser. I, I948) discussed in the report for Commission I4 has an important bearing on solar problems. For example, the lists of terms known in atomic spectra are being used to predict wave-lengths of important lines beyond I5,000 A. expected to be present in the solar spectrum; observations in this region have recently been reported from the Michigan Observatory. Since precise laboratory wave-lengths are lacking in this region the solar wave-length scale is based on predicted lines of leading multiplets of $\mathrm{Fe} \mathrm{I}$. Further identifications can be made by prediction, as has already been done in other regions of the solar spectrum.

With the advent of rocket solar spectrograms the Revised Multiplet Table is inadequate for astrophysical purposes. An Ultra-violet Multiplet Table similar in form to the I945 Table is being prepared. It will contain the laboratory data shorter than $3000 \mathrm{~A}$. of all spectra of astrophysical interest. No ultra-violet limit of wave-length is being imposed, although the multiplets needed at present for solar work lie between 2200 and $3000 \mathrm{~A}$. All observed ultimate lines of arc and first spark spectra are being listed if they are not in the Revised Multiplet Table. All lines that may be significant in connection with the appearance of forbidden lines in cosmical spectra are likewise being included. In this field, Moore Sitterly has the cordial collaboration of I. S. Bowen, who has 
generously furnished such a list to be used as a guide in preparing the new multiplet table.

Preliminary multiplet lists of laboratory data together with estimated solar intensities of lines to be expected in the solar spectrum between 2200 and $3000 \mathrm{~A}$. have been furnished to those engaged in the interpretation of rocket solar spectrograms. These lists will be incorporated into the Ultra-violet Multiplet Table. This Table is now complete for the spectra from $\mathrm{H}$ through $\mathrm{F}$ and for selected spectra of the elements $\mathrm{Na}$ through $\mathrm{A}$. The multiplet lists of the leading spectra of the first long period of the periodic table are also nearly final.

These large and important programmes, developed by Mrs Moore Sitterly, are being co-ordinated in an effort to furnish the astrophysicists with all relevant laboratory data on the analysis of atomic spectra, including unpublished material, which is generously being furnished by many collaborators.

Brück reports that the Irish Government is making a considerable effort to convert the Dunsink Observatory into an efficient modern observatory, where he plans to set up a solar spectroscopic installation.

In a long series of measures made by Evershed of the sodium line $D_{1}$ in the Sun and vacuum tube, with the high dispersion liquid prism spectrograph, evidence was obtained of marked variations of wave-lengths of this line, both at the centre of the disk and close to the limb. His recent work seems to indicate that similar variations on a much smaller scale of the wave-lengths of the iron lines in the region between 6280 and $6302 \mathrm{~A}$. are also present at a lower level.

Considerable work has been done at the Observatories of Meudon and of the Pic du Midi under the direction of Lyot on the spectro-photometry of prominences; three hundred lines have been measured between 3300 and II,000 A. The work will be extended to the faint prominences in order to investigate the relative variations of intensities. The radiation of the solar corona and the profile of its emission lines to various distances from the Sun's limb have been studied with Lyot's methods.

Lyot suggests that the intensity of the Fraunhofer lines be defined by the ratio of the total quantity of light absorbed to that which is contained in a band I A. wide of the continuous nearby spectrum. The definition could be extended to the emission lines, as for instance the ones of the prominences and of the corona, adopting the sign + for the emission lines and - for the absorption lines.

The intensity distribution at the extreme limb should present, in the opinion of Minnaert, an interesting subject. The work of Wesselink, Kopal, Wildt, Lindblad, and of Minnaert at the Yerkes Observatory could be compared. It would be worth while to ascertain whether the eclipse method is really useful or not.

This Commission, according to the suggestion of Minnaert, should urge the Union to accelerate the compilation of tables of atomic and molecular transition probabilities, which are so important for spectroscopic work.

Recent laboratory work done in Liège by Swings and Migeotte on molecular bands has received interesting solar applications.

All problems connected with the solar radiation which it is possible to investigate by radio methods are open to discussion, and it is desirable that the members of this Commission who are interested in them should have a joint meeting with members of the Commission for solar and terrestrial relationships.

D. H. Menzel reports the following items which may be useful for discussion in the meetings of Commission I2:

One of the most important contributions in recent years to solar spectroscopy is the photography of the solar ultraviolet from a V-2 rocket. Dr Richard Tousey, of the Naval Research Laboratory, and his collaborators were the first to accomplish this feat. Since then Dr Tousey, as well as other investigators, has obtained several additional spectra.

The spectra are of low dispersion, but the principal features are clearly visible. Most striking, perhaps, is the great intensity of the $\mathrm{Mg}$ II doublet at 2800 , which appears to be more intense than $\mathrm{H}$ and $\mathrm{K}$. These lines, incidentally, show a strong central emission component. 
The source of this central emission is probably similar to that giving rise to the cores of $\mathrm{H}$ and $K$. One would expect this intensity to be variable with the number of flocculi.

Additional lines of interest are the resonance line of $\mathrm{Mg} \mathrm{I}$, a strong line of Si I, and many lines attributable to the atoms of Fe I and Fe II ( $A p . J$. Io9, I, I949).

Among the more profitable lines of investigation, which would require extension of existing theories of the formation of absorption lines, is the interpretation of the spectrum of sunspots. Experimental determinations of the magnitude and rate of variations of magnetic fields of spots and the Sun itself are greatly to be desired. This information is particularly needed by physicists working in the field of cosmic rays.

Dr John W. Evans has recently designed new types of interferometric equipment, which may have a wide application to solar spectroscopy.

ARCETRI-FIRENZE

GIORGIO ABETTI

Jan. I4, I948

President of the Commission

Président: M. G. Abetti.

\section{Compte rendu de la séance}

Secrétaires: MM. M. Migeotte, G. Righini.

Le président ouvre la séance et signale brièvement les différentes questions qui doivent être discutées.

A propos des mesures de la constante solaire, M. Nicolet fait remarquer que la valeur de l'angle d'ouverture des actinomètres ne suffit pas pour définir leurs propriétés géométriques. Il faut aussi considérer ' l'angle limite' et 'l'angle de pente'. En observant cette précaution on peut tenir compte de l'effet d'une source uniforme (source de laboratoire ou lumière du ciel) et d'une source non-uniforme (soleil+ciel) dans le résultat des mesures. Une publication sur ce sujet paraîtra sous peu dans les Mémoires de l'Institut Météorologique d'Uccle (Belgique).

M. Link signale qu'il a observé un coefficient de corrélation s'élevant à 0.46 avec une erreur moyenne de 0.05 entre l'éclat de la lune et les variations de la constante solaire. Ceci s'expliquerait par une luminescence de la lune sous l'influence des radiations ultraviolettes du soleil. D'après Abbot, ce serait d'ailleurs l'intensité des radiations ultraviolettes qui serait la plus variable. M. Link fait aussi remarquer qu'une variation de I \% dans la constante solaire produit une variation 30 fois plus grande dans l'éclat de la lune.

Selon M. Brück, des observations photoélectriques d'Uranus ne révèlent aucune diminution d'éclat de la planète. Toutefois, d'après des observations visuelles effectuées à Yale de 1940 à I946, il y aurait une variation de 0.6 magnitudes.

M. Nicolet fait remarquer que si une corrélation est observée entre la constante solaire et l'éclat d'un astre, il ne faut pas nécessairement en déduire qu'il y a une variation dans la constante solaire; car, dans les deux cas, les variations peuvent provenir de l'atmosphère terrestre.

M. Stratton émet l'opinion qu'il doit exister de grandes variations d'intensité dans le rayonnement ultra-violet solaire ainsi que dans le domaine des ondes de radio.

M. Öhman suggère des mesures de la polarisation circulaire des ondes de radio pendant les éclipses partielles.

M. Menzel fait ensuite la communication suivante:

To explain the variation of ionization in the $E$ and $F_{1}$ layers, it is necessary to suppose a variation of 1 to $I 6$ between sunspot minimum and maximum. A similar variation is probably necessary to explain the variation in the $\mathrm{F}_{2}$ layer but the simpler ionospheric theory does not apply in all details. Hence there is more uncertainty. All three layers show a high correlation between the observed ionization and the sunspot number. 
M. Nicolet fait remarquer qu'il ne faut pas confondre l'ultra-violet observable $(\lambda \simeq 3000$ A.) et atteignant le sol avec l'ultra-violet $(\lambda<$ IO00 A.) n'atteignant que la haute atmosphère.

M. Kiepenheuer signale que les observations de Hale concernant le champ magnétique solaire ne sont pas confirmées. D'après les dernières mesures de Thiessen, le champ serait certainement, en ce moment, plus petit que 5 gauss. On ne peut dire si le champ est réellement nul ou est périodique.

Des observations de Evershed effectuées avec un prisme liquide semblent montrer que le champ n'existe pas. M. Nicholson donne connaissance d'un rapport de Babcock sur le même sujet. D'après les toutes dernières observations de ce dernier, les mesures n'ont plus permis de déceler un champ magnétique solaire. Stratton pense que les travaux doivent être continués avant de tirer une conclusion définitive.

Mme Moore Sitterly attire l'attention sur la révision des tables de Rowland de 3063 à $6600 \mathrm{~A}$., travail qui n'est pas publié jusqu'à présent. Elle signale aussi la publication des niveaux 'd'énergie atomique' de l'hydrogène au fluor (Cir. Nat. Bur. St. 467, vol. I, sér. I, I948). Le travail est actuellement continué au Bureau of Standards (Washington, D.C.). Le volume I s'étendra de l'hydrogène au vanadium.

A propos de la publication des tables révisées de Rowland, faut-il introduire des données sur les spectres des taches et y a-t-il lieu actuellement d'étendre le domaine spectral jusque $24000 \mathrm{~A}$., en tenant compte des derniers travaux effectués à l'Université de Michigan? MM. Minnaert, Goldberg, Swings et Nicholson émettent leur avis à ce sujet. A la suite de cette discussion, le président invite M. Swings à rédiger une résolution qui sera soumise au Comité exécutif. Voici le texte adopté par la Commission:

Commission 12 considers that the publication of a revised table of the solar spectrum at the earliest possible time is of the greatest importance to astronomers engaged in solar research and in the investigation of stellar spectra. In order to reduce the delay in publication, Commission I2 recommends that the revised table be limited to the still unpublished spectral range from $\lambda_{3063}$ to $\lambda 6600$, and that the wave-lengths be given on the scale of 1928 . To this purpose, Commission 12 recommends that the I.A.U. provides financial aid for the publication of the revised solar table for an amount of $£ 500(\$ 2000)$.

M. Plaskett demande si les intensités des raies dans les tables révisées seront données d'après l'Atlas d'Utrecht. M. Minnaert marque son accord à ce sujet et signale que la Commission 36 doit décider s'il convient d'adopter $\Delta \lambda$ ou $\Delta \lambda / \lambda$ pour les largeurs équivalentes.

M. Menzel signale que les chercheurs engagés dans l'étude des rayons cosmiques sont particulièrement intéressés par les mesures des champs magnétiques du soleil et des taches solaires. Il y a lieu de poursuivre activement des travaux dans ce domaine.

M. Nicholson fait remarquer que la surface d'une tache ou d'un groupe de taches n'a pas de relation avec le champ magnétique. C'est la surface de l'ombre qui est en relation avec l'intensité du champ radial; tandis que celle du champ parallèle dépend de la distance entre les ombres de polarité opposée, d'où une méthode facilement applicable pour juger de l'intensité du champ dans les différentes taches.

M. Kiepenheuer signale qu'il est aussi important de déterminer le champ au voisinage des taches en vue d'une comparaison avec le champ d'excitation de la chromosphère. Toutefois, vu le temps nécessaire pour ces mesures, l'étude ne peut être entreprise que pour des taches sélectionnées.

Pour terminer, M. Minnaert fait connaître les résultats qu'il a récemment obtenus à l'Observatoire Yerkes, concernant l'obscurcissement au bord du disque solaire. Des résultats ont été obtenus par photométrie photographique pour une région du disque comprise entre $90 \%$ et $99.5 \%$ et pour les longueurs d'onde 5600 et $6250 \mathrm{~A}$. 


\section{Problèmes Relatifs au Rayonnement de L'Atmosphère Solaire}

Il existe des preuves expérimentales et des raisons théoriques pour le rayonnement assez intense de l'atmosphère solaire dans le domaine inaccessible aux observations terrestres. Je voudrais attirer l'attention sur l'excès de lumière dans la pénombre pendant les éclipses de lune qui peut être en relation avec notre thème.

Il est un fait bien établi qu'il y a un excès de lumière dans la pénombre, variable d'une éclipse à l'autre, excès qui augmente vers le bord de l'ombre, et qui à 5 ' du bord, peut atteindre par rapport à la valeur théorique facilement $\mathrm{o}^{\mathrm{m} \cdot 5}$ à $\mathrm{o}^{\mathrm{m}} \cdot 75$. Comme la valeur théorique de l'éclairement dans la pénombre est bien établie et qu'il n'y a aucune explication plausible, je me suis demandé, si ce n'est pas l'atmosphère solaire qui en est la cause. En effet, dans la pénombre, assez près du bord de l'ombre, le disque solaire est beaucoup plus éclipsé que son atmosphère et il peut en résulter l'excès que l'on a constaté. L'éclairement direct optique par l'atmosphère solaire étant trop faible, on peut penser à la luminescence de la surface lunaire sous l'influence des rayons ultraviolets solaires.*

On arrive à interpréter l'excès moyen en admettant que dans la lumière de la pleine lune il y a en moyenne ro \% de la composante luminescente. Dans cet ordre d'idées on devrait rencontrer des fluctuations dans la lumière de la lune en dehors de l'éclipse. Les mesures de Rougier† se prêtent très bien à ce genre de recherches. Je les ai employées en corrélation avec les variations simultanées de la constante solaire trouvées par Abbot.† On arrive donc au résultat suivant:

$$
r=+0.44 \pm 0.05 \text { (e.p.) } n=94 \text {. }
$$

La corrélation paraît donc assez bien établie et donne en quelque sorte la première preuve indirecte des variations de la constante solaire que l'on a en vain cherchée dans les fluctuations de la lumière de Jupiter et de ses satellites et d'Uranus. Il est aussi remarquable que les variations lunaires sont environ 30 fois plus grandes que les variations de la constante solaire. On devrait rapprocher ce fait avec les résultats de Abbot et de Péttit sans parler des résultats ionosphériques qui accusent tous des variations croissantes vers l'extrémité ultraviolette du spectre.

Si l'hypothèse du travail proposé s'affirme, nous aurons la possibilité d'étudier les variations du rayonnement solaire inaccessible aux observations terrestres. On peut songer, en plus des éclipses et de la lumière globale de la lune, à l'intensité résiduelle des raies de Fraunhofer, comme il ressort de la discussion avec MM. Brück, Kiepenheuer, Dufay et autres.

F. LINK

\section{REPORT ON URANUS OBSERVATIONS}

Brück reports that at Cambridge he has made series of photoelectric observations of Uranus with a view to determine possible variations of the solar constant. The observations extend over an interval of about 5 years, but there are some gaps in the series, and the observations are to be continued at Dunsink.

The reduction of the observations and, in particular, the separation of effects due to possible solar variations from those due to Uranus itself, has not yet been completed.

H. A. BRücK

\section{Photographic Measurements of the Solar Limb Darkening}

The measurement of the limb darkening is of the greatest importance for establishing a model of the outer layers. Especially the zone very near to the limb should be studied, because this conveys information on the structure of the highest layers, where a great part of the Fraunhofer lines originates.

* F. Link, C.R. 223 (1946); Bull. Soc. Math. Phys. Tchéc. 72 (1947), n. 65.

$\dagger$ G. Rougier, Ann. Obs. Strasbourg, 2 (1933), p. I3.

$\ddagger$ Annals of the Smith. Instit. vol. 6. 
Up to now, the observations belong to two groups:

I. Measurements between 0 and $98 \%$ of the radius (Abbot, Moll c.s., Raudenbusch, Chalonge).

2. Measurements between 99.3 and I0o \%, obtained at total eclipses (Wesselink, Kopal, Lindblad).

It was important to bridge the gap and to study especially the regions near the limb.

A series of photographs of the Sun's disk, taken at the Yerkes Observatory in the summer of I946, was measured at Utrecht by Miss van den Hoven van Genderen and by $\mathrm{Mr}$ van Diggelen. The image had a diameter of $\mathrm{I} 8 \mathrm{~cm}$. The plates had been calibrated, they refer to the wave-lengths $\lambda 6250$ and $\lambda 5600$. Corrections for sky light, chromatic aberration and scintillation were applied. The mean deviation due to scintillation proved of the order of $0.003 \mathrm{R}$, which corresponds to very good conditions of seeing.

The limb darkening was measured between $90 \%$ and $99.5 \%$ of the radius, the point at $90 \%$ being provisionally taken from Abbot. Well consistent and apparently reliable results were obtained from the different plates.

There is no doubt, that photographic photometry of such sharp photographs must yield quite reliable results even near the extreme limb, and that it would be very useful if other observers could repeat these measurements for different wave-lengths.

\begin{tabular}{|c|c|c|c|c|c|c|c|c|c|c|c|}
\hline$\% \mathrm{R}$ & 90 & 91 & 92 & 93 & 94 & 95 & 96 & 97 & 98 & 99 & $99_{5}$ \\
\hline$\lambda 5650$ & $65 \cdot 3$ & $63 \cdot 7$ & $61 \cdot 7$ & $59 \cdot 7$ & $57 \cdot 5$ & $55 \cdot 3$ & $52 \cdot 6$ & $49 \cdot 3$ & $44 \cdot 5$ & 38.6 & $35 \cdot 0$ \\
\hline$\lambda 6250$ & 67.9 & $65 \cdot 8$ & $63 \cdot 9$ & $61 \cdot 8$ & $59 \cdot 6$ & 57.4 & $54 \cdot 7$ & $51 \cdot 5$ & $47 \cdot 7$ & $42 \cdot 6$ & 39 . \\
\hline
\end{tabular}

M. MinNAERT 